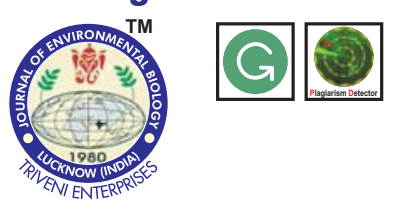

\title{
Histopathological alterations in the kidneys of Labeo rohita due to lead toxicity
}

Authors Info

\section{O. S. Brraich* and M. Kaur}

Department of Zoology and Environmental Sciences, Punjabi University, Patiala-147 002, India

${ }^{*}$ Corresponding Author Email : singhonkar@yahoo.com

Key words

Lead toxicity,

Aquatic ecosystem,

Labeo rohita, Kidney,

Histopathology

Publication Info

Paper received : 15.04 .2015

Revised received: 04.02.2016

Accepted : 06.06.2016

\section{Abstract}

Aim : Lead is one of the most hazardous heavy metal and is known to cause cancer and affects reproduction, liver, thyroid and kidney functions of the organisms. To know more about lead toxicity, a toxicity test was conducted on the healthy fingerlings of Labeo rohita and histopathological alterations were studied.

Methodology : The stock solution of lead nitrate was prepared and the test fingerlings were exposed to four sublethal concentrations on the basis of $1 / 3 \mathrm{rd}, 1 / 5$ th, $1 / 7$ th and $1 / 10$ th of $\mathrm{LC}_{50}$ value i.e., $11.4 \mathrm{mg} \mathrm{l}^{-1}, 6.84$ $\mathrm{mg} \mathrm{l}^{-1}, 4.88 \mathrm{mg} \mathrm{l}^{-1}$ and $3.42 \mathrm{mg} \mathrm{l}^{-1}$, respectively. One fingerling from each dose was sacrificed after $15,30,45$ and 60 days of exposure and dissected to remove the kidney tissues. The tissues were washed in buffer and fixed in $10 \%$ formalin, dehydrated in ascending grades of alcohol, cleared in xylene and embedded in parafin wax. The wax blocks were then further processed for section cutting and staining. The sections were viewed under light microscope and histological alterations were studied.

Results : The histopathological changes such as cellular hypertrophy, vacuolation of epithelial cells of renal tubules, glomerular distortion, increase in the space of Bowman's capsule, occlusion of lumen of renal tubule, loosening of the haemopoeitic tissue, disruption of tubular organisation, nuclear hypertrophy, picnotic nuclei, karyolysis, karyorrhexis, tubular and glomerular degeneration, lymphocytic infiltration, melanomacrophage aggregates and tubular necrosis were observed in all the treatments.

Interpretation: The damage increased with the increase in the dose of lead nitrate and days of exposure. The addition of heavy metals in aquatic ecosystems is a matter of great concern because it causes failure of vital organs in fish. Therefore, industrial effluents should be discharged in natural waters after proper treatment for protection and sustainability of valuable fish fauna.

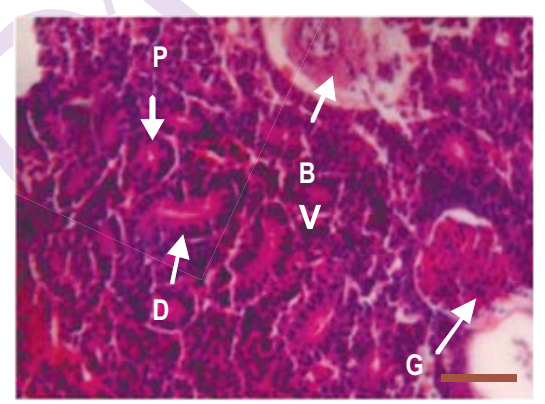

Fig.1: Microphotograph of kidney of Labeo rohita in control. $B a r=20 \mu \mathrm{m} . P=$ Proximal tubule, $D=$ Distal tubule, $\mathrm{G}=$ Glomerulus, $\mathrm{BV}=$ Blood vessel

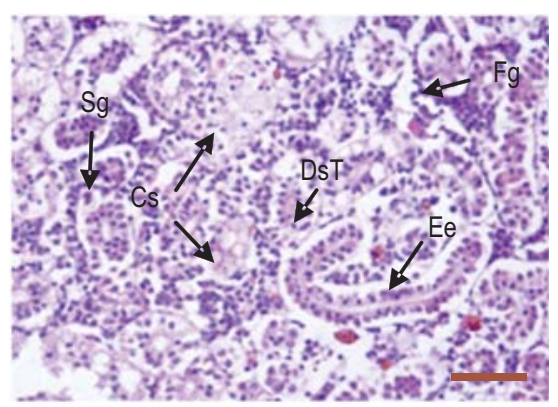

Fig. 2: Microphotograph of kidney of Labeo rohita on being exposed to $11.4 \mathrm{mg} \mathrm{l}^{-1}$ of lead nitrate after 60 days. Bar $=20 \mu \mathrm{m} . \mathrm{Sg}=$ Shrunken Glomerulus, $\mathrm{Cs}=$ Cloudy Swelling, Dst $=$ Deshaped Tubules, Ee $=$ Exfoliated Epithelium, $\mathrm{Fg}=$ Fragmented Glomerulus 


\section{Introduction}

Lead based pollution is rising unprecedently in aquatic ecosystems. It is largely due to various anthropogenic activities like discharge of pollutants from industries such as mining, chemical, pesticides and fertilizer, exhausts of vehicles and even cyanide which further deteriorates the physico-chemical properties of water. However, these pollutants build up in the food chain and are responsible for adverse effects and even cause death of aquatic organisms (Loumbourdis, 1997 and Farkas et al., 2002). Pollutants also enter the aquatic ecosystems from urban, agricultural runoff, atmospheric precipitation, plating processes, use of phosphate fertilizers and a variety of natural sources including erosion and volcanic emissions. Besides above said sources of pollution, lead is one of the major pollutant causing agents these days because it is often used in variety of industrial applications and products such as battery production, chemical pigments and paints. But, lead seems to lack biological functions and is very toxic for aquatic organisms even in small doses and causes histopathological alterations in various vital organs in fish (Stouthart et al., 1994; Cavas, 2008 and Sirimongkolvorakul etal., 2012).

Heavy metals have long been recognized as serious pollutants in the aquatic environment which affect fish population, reducing their growth, reproduction efficacy and survival rate (Obasohan et al., 2008). Bioaccumulation of these pollutants in the tissues of fish causes various histopathological changes in the vital organs like gill, kidney and liver, which are essential for respiration, excretion, accumulation and biotransformation of xenobiotics in fish (Gernhofer et al., 2001 and Javed and Usmani, 2011). The histopathological biomarkers have been widely used as tools for the detection and assessment of the effects of exposure of pollutants in various tissues of fish (Oliveira Ribeiro et al., 2006; Mohamed, 2009 and Butchiram et al., 2013), but there is paucity of literature on the kidney tissues of fish exposed to lead. As kidneys are one of the primary organs involved in excretion, homeostasis and osmoregulation, but malfunctioning and failure of removal of poisonous substances by kidney have been observed due to various histopathological alterations in these organs (Jobling, 1995). Hence, keeping in view of the above considerations, the present course of work is an endeavour to conduct histopathological alterations caused by lead nitrate on the kidney tissues of the fish, Labeo rohita.

\section{Materials and Methods}

Healthy fingerlings of Labeo rohita (size $10 \pm 1 \mathrm{~cm}$ and $10 \pm 2 \mathrm{~g}$ by weight) were brought to the laboratory from Nanoki fish farm located near Patiala in polythene bags filled with oxygenated water. They were disinfected with $0.1 \% \mathrm{KMnO}_{4}$ for 30 min to remove any external infections. Then they were acclimatized to laboratory conditions in a non-chlorinated tap water for 15 days in a water tank of 1000 I capacity. The water was changed after every $48 \mathrm{hrs}$ and the fish were fed with pelleted feed having all the essential nutrients (APHA, 2012).

Stock solution was prepared by dissolving lead nitrate in distilled water to conduct the toxicity tests. The water of the test tanks was changed every $24 \mathrm{hrs}$ and fresh solution of lead nitrate was added to each test tank. The fish were exposed to four sublethal concentrations of lead nitrate i.e., $1 / 3^{\text {rd }}, 1 / 5^{\text {th }}, 1 / 7^{\text {th }}$ and $1 / 10^{\text {th }}$ of $\mathrm{LC}_{50}$ value (34.20 $\mathrm{mg} \mathrm{l}^{-1}$ ) (Brraich and Kaur, 2015) and which were $11.4 \mathrm{mg} \mathrm{l}^{-1}, 6.84 \mathrm{mg} \mathrm{l}^{-1}, 4.88 \mathrm{mg} \mathrm{l}^{-1}$ and $3.42 \mathrm{mg} \mathrm{l}^{-1}$ respectively. Ten healthy fingerlings were exposed to different sub-lethal concentrations of lead nitrate and one group was kept as a control. Test fingerlings from each tank were sacrificed after $15,30,45$ and 60 days of exposure and dissected to remove the kidney tissues. They were washed and fixed in $10 \%$ formalin, dehydrated in graded series of alcohol, cleared in xylene and embedded in paraffin wax. The wax blocks were then prepared and processed for section cutting. Thin sections of $5 \mu \mathrm{m}$ were prepared using rotatory microtome. The sections were mounted on the slides and stained with Ehrlich's haematoxylin-eosin stain stain and mounted in Canada balsam (Humanson, 1972). The slides were observed under light microscope and photomicrographs were taken for further analysis.

\section{Results and Discussion}

Histological study showed a typical structural organization of the kidneys in untreated fish (Fig. 1A-1B), but on being treated with different concentrations of lead nitrate histopathological changes were observed after 15 days of treatment in the kidney of Labeo rohita which included cloudy swelling of the tubules, vacuolation of epithelial cells in the renal tubules, shrunken glomerulus, increase in the space of Bowman's capsule, haemolysis and loosening of the haemopoeitic tissue (Fig. 2A); mild swelling of renal tubules with wider lumen, a marked dilation of glomerular capillaries, increase in the space of Bowman's capsule, vacuolation in the tubular cells, melanomacrophages aggregates (Fig. 2B); increased melanomacrophage aggregates, decrease in intertubular space, shrunken glomerulus, increase in the space of Bowman's capsule, increased loosening of haemopoeitic tissue (Fig. 2C); disruption of tubular organisation, deshaped tubules, shrunken glomerulus, pyknotic nuclei, haemorrhage and loss of compactness of haemopoietic tissue (Fig. 2D). Similar results were observed by Roy and Bhattacharya (2006) in the kidney of Channa punctatus on exposure to subletahal concentrations (1/10 LC 50 and $\left.1 / 20 L_{50}\right)$ of arsenic for two weeks. Tubular necrosis was reported by Latif et al. (2013) in Labeo rohita on being exposed to lead nitrate and copper sulphate. These are in agreement with the present study. Wangsongsak et al. (2007) reported shrinkage in the glomeruli, vacuolisation and necrotic changes like oedema, pycnosis, karyorrhexis, karyolysis in Puntius gonionotus on being exposed to cadmium for three months. 

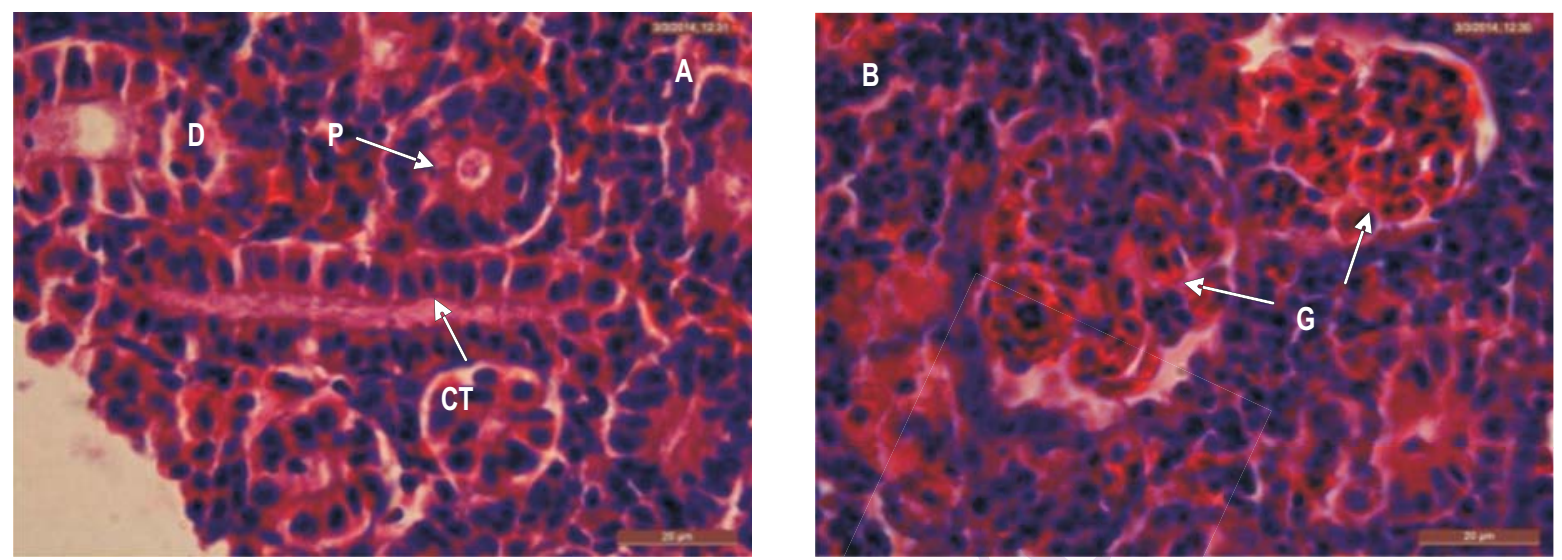

Fig. 1 : Microphotograph of the kidney of Labeo rohita in control. Bar= $20 \mu \mathrm{m}$; Abbreviations: $P=$ Proximal tubule, $D=D i s t a l$ tubule, $G=G l o m e r u l u s, ~ B=$ Blood vessel; $\mathrm{CT}=$ Collecting tubule

Treatment of fish for 30 days with different concentrations revealed indistinguishable shape of the kidney cells, lumen of the tubules decrease in size, swollen and vacuolated tubular cells, fragmented and atrophied glomerulus (Fig. 3A); irregular shape of renal tubules, extensive hydropic swelling, pyknotic nuclei (Fig. 3B); dilation of the tubular lumen, cellular hypertrophy, accumulation of lipid vacuoles, irregular shaped pyknotic nuclei, disorganization of glomerulus (Fig. 3C); loss of cellular integrity, severe swelling of the renal tubules, cellular hypertrophy, rupture of cells, accumulation of lipid vacuoles, infiltration of edematous fluid (Fig. 3D). Similar alterations and pathological changes were found in fish exposed to environmental contaminants in Lates calcarifer (Thophon et al., 2003), Channa punctatus (Gupta and Srivastava, 2006), Cirrhinus mrigala (Gupta and Kumar, 2006), Onchorhynchus mykiss (Banaee et al., 2013).

The changes observed in fish kidney on exposure to lead nitrate for 45 days include exfoliated epithelium, severe swelling, cellular atrophy, nuclear hypertrophy, shrunken and fragmented glomerulus (Fig. 4A); exfoliated epithelium, cytoplasmic vacuolation, eosinophilic granules, breakage of tissue, swollen nuclei of the cells undergoing karyorhexis (Fig. 4B); irregular diameter of renal tubules, edema in the cells of renal tubules, disrupted cell boundaries, fragmentation of nuclear chromatin, nuclear vacuolation, damage and disorganisation of renal corpuscle (Fig. 4C); degeneration of tubular cells and glomerulus, reduction in cell number in the renal tubules, narrowness of tubular lumen, enlarged necrotic nuclei in syncytial condition, congestion of blood vessel, leukocyte infiltration (Fig. 4D). These results are in agreement with Parvathi et al. (2011); Ghosh and Mandal (2012) and Ruqaya et al. (2013) who reported edema as the first sign of renal manifestation in Cyprinius carpio on being exposed to heavy metals. They also reported prominent tubular degeneration with severe interstitial mononuclear inflammatory cells, damaged haemopoietic tissues and uriniferous tubules, shrinkage in glomeruli with reduced Bowman's space on being exposed to heavy metals.

On 60 day treatment with lead nitrate the fish kidney showed vacuolated cells, enlarged nuclei, degeneration and necrosis of tubules and glomerulus and drastic decrease in the haemopoeitic tissue, degeneration in some nuclei (Fig. 5A); destruction of tubules, loss of intercellular partitions, cytoplasmic degeneration, tubular and glomerular necrosis and karyolysis (Fig. 5B); degeneration of cytoplasm of tubular and glomerular cells, hyaline droplet degeneration, nuclear degeneration, edema in tubules and glomerulus (Fig. 5C); degeneration and necrosis of cells of renal tubules and renal corpuscles leading to complete necrosis of the kidney tissues, nuclear necrosis, haemopoietic necrosis, irregular blood congestion (Fig. 5D). Similar alterations were reported by Dar et al. (2011) and Bilal et al. (2011) in Clarias batrachus on being exposed to cadmium chloride. Malik et al. (2013) reported necrosis and tissue damages in renal tubules of Clarias gariepinus exposed to mercuric chloride.

Since the renal tubular epithelium has a major function in excretion of divalent ions, the lesions in the nephrons and haemopoeitic tissues suggests impaired osmotic and ionic regulation due to altered metabolic activity caused by interaction of heavy metal and renal tissue. These interactions may lead to excretory disorders and interrenal exhaustion as suggested by Gupta and Srivastava (2006). The histopathological changes observed in the kidneys of fish, Labeo rohita on being exposed to different concentrations of lead nitrate such as degenerated tubular epithelium, shrinkage and degenerating glomerulus indicate kidney failure of the fish. This is in agreement with the earlier studies (Gupta and Kumar, 2006; Roy and Bhattacharya, 2006; Butchiram et al., 2013).

Kidney is one of the primary organs and plays a pivotal role in excretion by removing toxicants from the body. During the 

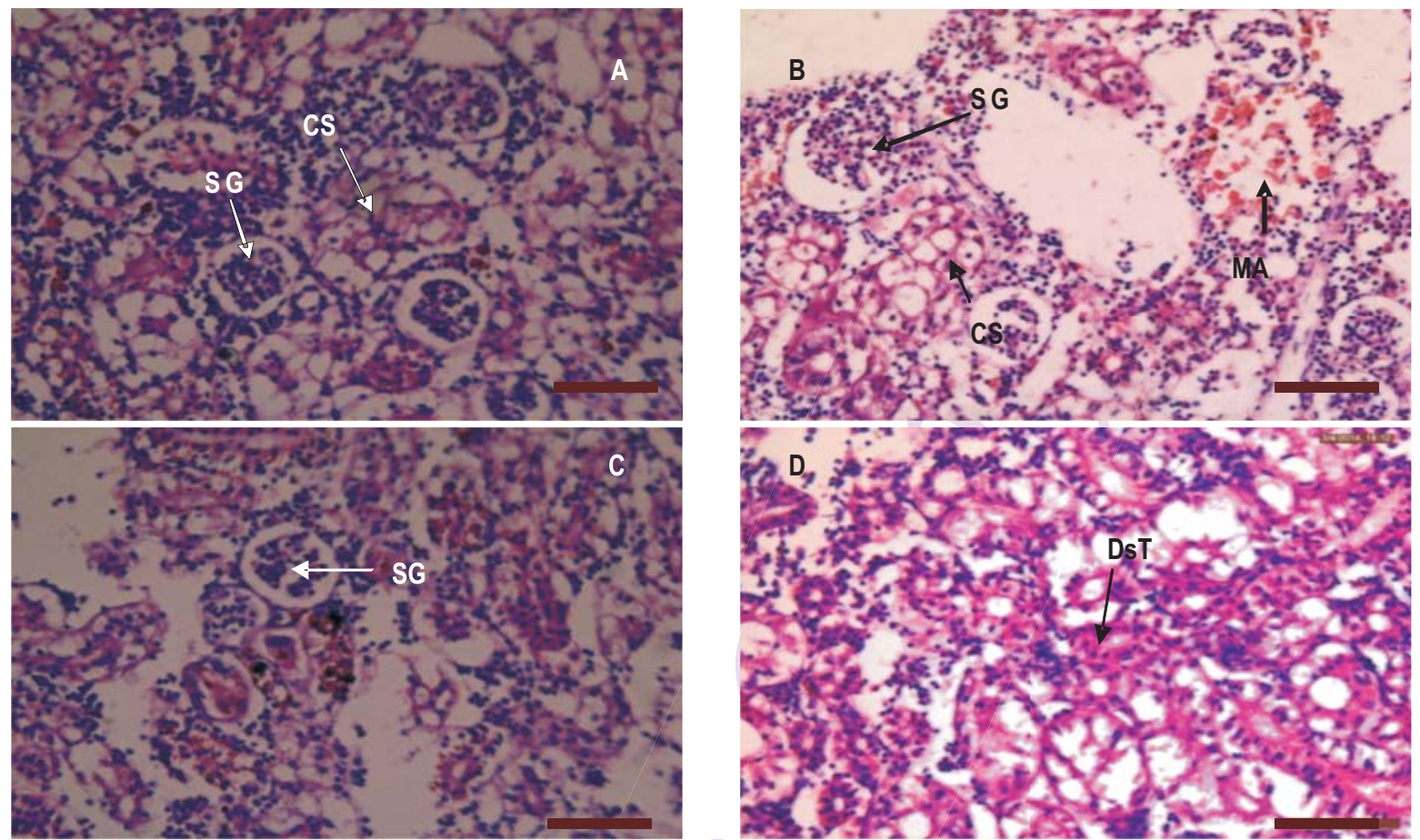

Fig. 2 : Microphotograph of kidney of Labeo rohita after 15 days of exposure to lead nitrate. A: $3.42 \mathrm{mg} \mathrm{l}^{-1} ; \mathrm{B}: 4.88 \mathrm{mg} \mathrm{l}^{-1} ; \mathrm{C}: 6.84 \mathrm{mg} \mathrm{l}^{-1}$ and D: $11.4 \mathrm{mg} \mathrm{l}^{-1}$. Bar=20 $\mu \mathrm{m}$. Sg=Shrunken Glomerulus, $\mathrm{Cs}=$ Cloudy Swelling, $\mathrm{Ma}=$ Melanomacrophage Aggregates, Dst= Deshaped Tubules
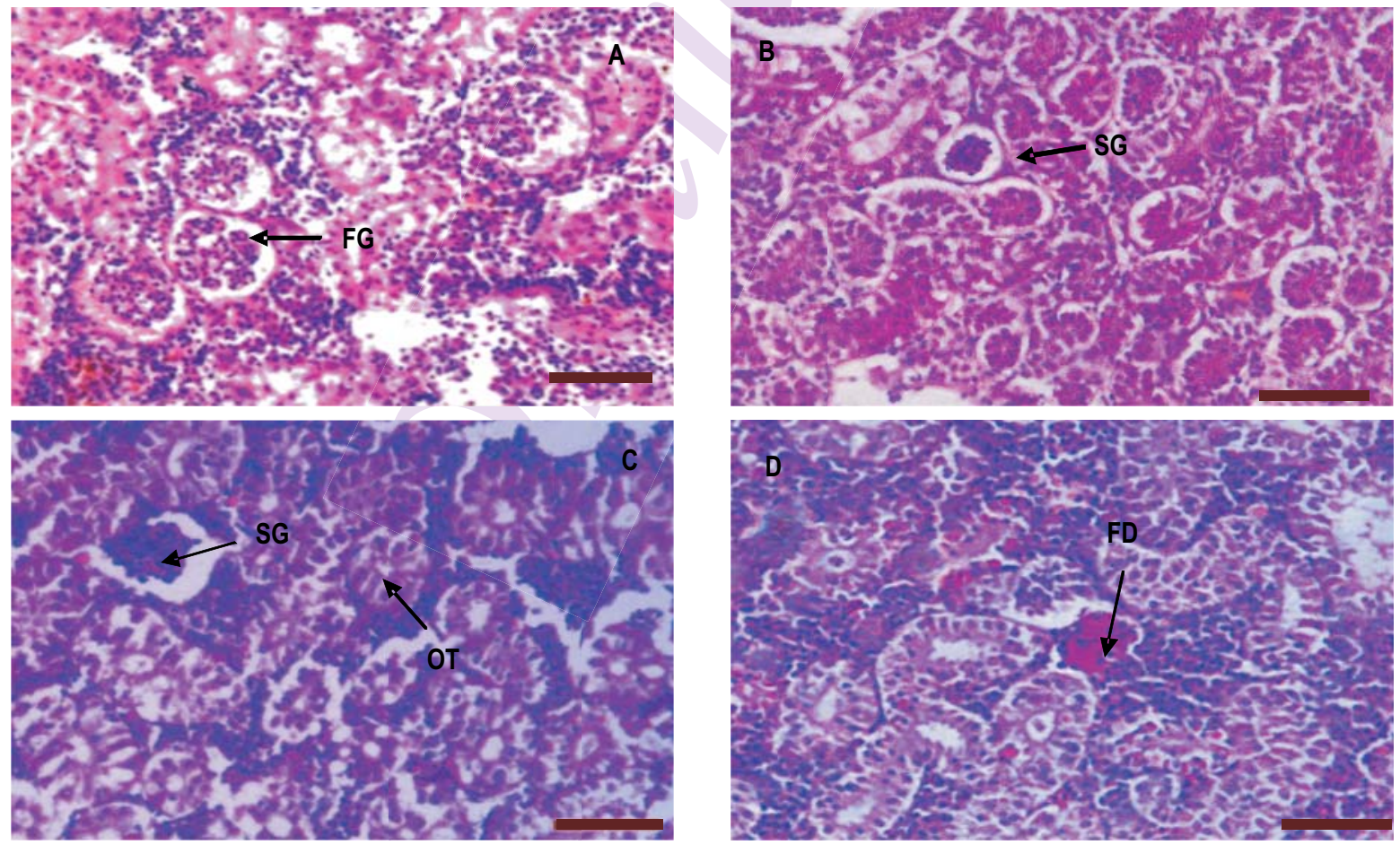

Fig. 3 : Microphotograph of kidney of Labeo rohita after 30 days of exposure to lead nitrate. A: $3.42 \mathrm{mg} \mathrm{l}^{-1}$; B: $4.88 \mathrm{mgl}^{-1} ;$ C: $6.84 \mathrm{mg} \mathrm{l}^{-1}$ and D: $11.4 \mathrm{mg} \mathrm{l}^{-1}$. Bar $=20 \mu \mathrm{m} . \mathrm{Fd}=$ Fragmented glomerulus, $\mathrm{Sg}=$ Shrunken glomerulus, Fd= Fat droplet, Ot= Occlusion of tubules 

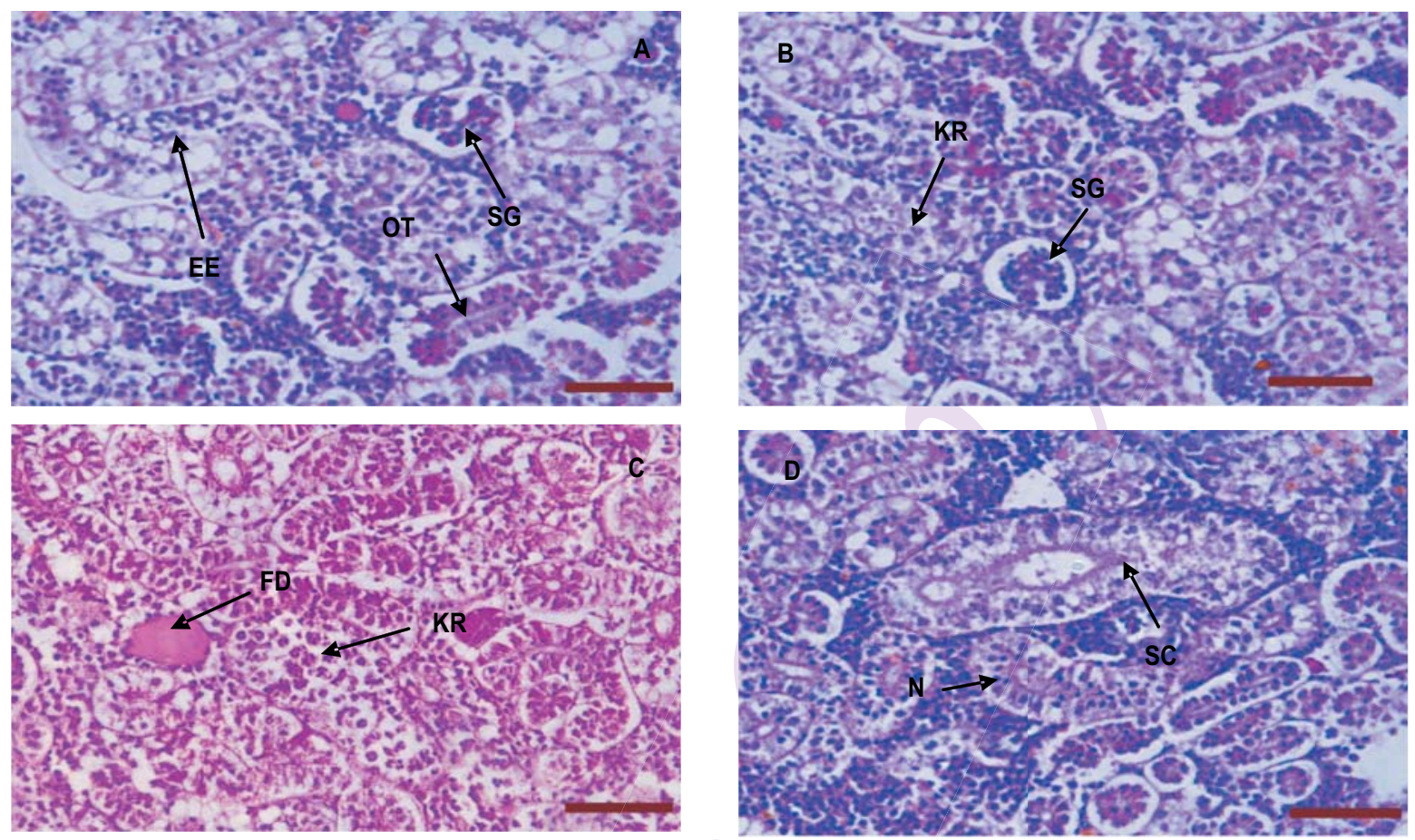

Fig. 4 : Microphotograph of kidney of Labeo rohita after 45 days of exposure to lead nitrate. A: $3.42 \mathrm{mg} \mathrm{I}^{-1} ; B: 4.88 \mathrm{mgl}^{-1} ;$ C: $6.84 \mathrm{mgl}^{-1}$ and D: $11.4 \mathrm{mg} \mathrm{l}^{-1}$. $\mathrm{Bar}=20 \mu \mathrm{m} . \mathrm{N}=$ Necrosis, Fd= Fat droplets, $\mathrm{Kr}=$ Karyorhexis, Ee= Exfoliated epithelium, Sg= Shrunken glomerulus, Ot= Occlusion of tubules, $\mathrm{Sc}=$ Syncytial condition
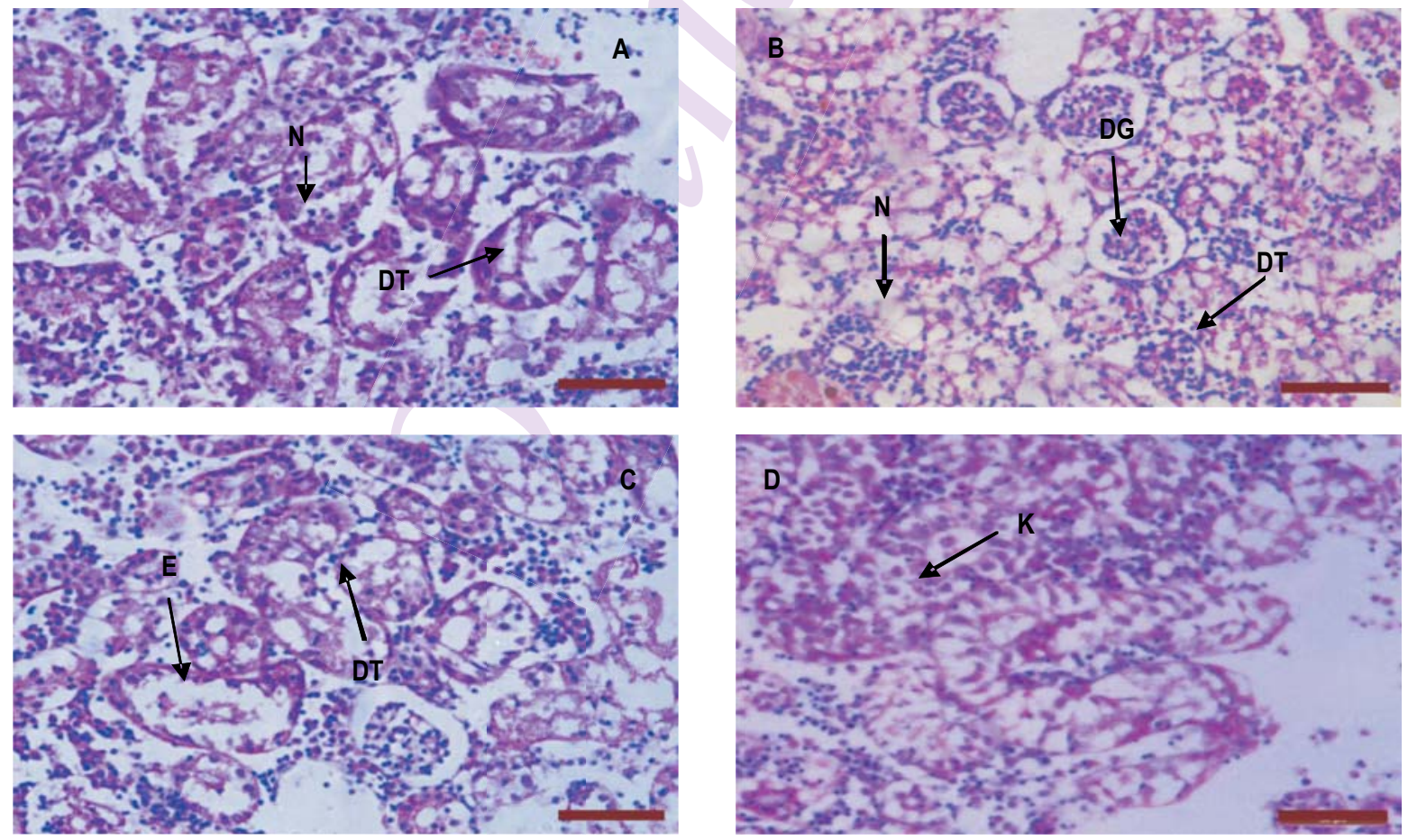

Fig. 5 : Microphotograph of kidney of Labeo rohita after 60 days of exposure to lead nitrate. A: $3.42 \mathrm{mg} \mathrm{l}^{-1} ; \mathrm{B}: 4.88 \mathrm{mg} \mathrm{l}^{-1} ; \mathrm{C}: 6.84 \mathrm{mg} \mathrm{l}^{-1}$ and D: $11.4 \mathrm{mg} \mathrm{l}^{-1}$. Bar $=20 \mu \mathrm{m}$. Abbreviations: $\mathrm{N}=$ Necrosis, $\mathrm{Dt}=$ Degenerating tubules, $\mathrm{E}=\mathrm{Edema}, \mathrm{K}=\mathrm{Karyolysis}, \mathrm{D}=$ Degenerating glomerulus 
present study it was observed that the kidney cells were massively destroyed due to infestation of lead nitrate. The damages were increased with increase in dose and duration. Due to malfunctioning of the kidney, removal of toxicants from the body of the fish was hindered which led to mass mortality of valuable fish fauna. Furthermore, it is concluded that lead nitrate toxicity can cause heavy loss to valuable fish diversity existing in our natural aquatic ecosystems. It is suggested that industrial effluents should be discharged after their prior purification at water treatment plants.

\section{Acknowledgment}

Authors are thankful to the Head, Department of Zoology and Environmental Sciences, Punjabi University, Patiala for providing necessary laboratory facilities to conduct present course of research work.

\section{References}

APHA: American Public Health Association: Standard methods for the examination of water and waste water. $22^{\text {nd }} \mathrm{Edn}$., Washington D.C. (2012).

Banaee, M., A. Sureda., A.R. Mirvagefei and K. Ahmadi: Histopathological alterations induced by diazinon in Rainbow trout (Oncorhynchus mykiss). Int. J. Environ. Res., 7, 735-744 (2013).

Bilal, A., T.A. Qureshi, S. Manohar, P. Kaur and R. Khaliq: Effect of cadmium chloride on the histoarchitecture of liver and kidney of a freshwater catfish, Clarias batrachus. Int J. Environ. Sci., 2, 531536 (2011).

Brraich, O.S. and M. Kaur: Determination of $\mathrm{LC}_{50}$ of lead nitrate for a fish, Labeo rohita (Hamilton-Buchanan). Int. Res. J. Biol. Sci., 4, 23-26 (2015).

Butchiram, M.S., M.V. Kumar and K.S. Tilak: Studies on the histopathological changes in selected tissues of fish Labeo rohita exposed to phenol. J. Environ. Biol., 34, 247-251 (2013).

Cavas, T.: In vivo genotoxicity of mercury chloride and lead acetate: Micronucleus test on acridine orange stained fish cells. Food Chem. Toxicol., 46, 352-358 (2008).

Dar, B.A., T.A. Qureshi and R. Khaliq: Effect of cadmium chloride on the histoarchitecture of certain organs of a freshwater catfish, Clarias batrachus. OurNat., 9, 83-88 (2011).

Farkas, A., J. Salanki and A. Specziar: Relation between growth and the heavy metal concentration in organs of bream Abramis brama $\mathrm{L}$. populating lake Balaton. Arch. Environ. Contam. Toxicol., 43, 236$243(2002)$.

Gernhofer, M., M. Pawet, M. Schramm, E. Muller and R. Triebskorn: Ultrastructural biomarkers as tools to characterize the health status of fish in contaminated streams. J. Aqua. Ecosys. Stress Recovery, 8, 241-260 (2001).

Ghosh, D. and D.K. Mandal: Histopathological effects and bioaccumulation of mercury in the kidney of an Indian major carp, Labeo rohita (Hamilton). Bull. Environ. Contam. Toxicol., 89, 479$483(2012)$.

Gupta, A.K. and A. Kumar: Histopathological lesions in the selected tissues of Cirrhinus mrigala (Ham.) fingerlings exposed to a sublethal concentration of mercury. J. Environ. Biol., 27, 235-240 (2006).
Gupta, P. and N. Srivastava: Effects of sub-lethal concentrations of zinc on histological changes and bioaccumulation of zinc by kidney of fish, Channa punctatus (Bloch). J. Environ. Biol., 27, 211-216 (2006).

Humanson, G.L.: Animal tissue techniques (Eds.: W.H. Freeman and Co.). $3^{\text {rd }}$ Edn., San Fransisco (1972).

Javed, M. and N. Usmani: Accumulation of heavy metal in fishes: A human health concern. Int. J. Environ. Sci., 2, 659-670 (2011).

Jobling, M.: Environmental Biology of Fishes. ${ }^{\text {st }}$ Edn., Chapman And Hill Publishers, London (1995).

Loumbourdis, N.S.: Heavy metal contamination in a lizard, Agama stellio stellio compared in urban, high altitude and agricultural, low altitude areas of North Greece. Bull. Environ. Contam. Toxicol., 58, 945-952 (1997)

Latif, A., M. Ali, A.H. Sayyed, F. Iqbal, K. Usman, M. Rauf and R. Kaoser: Effect of copper sulphate and lead nitrate administered alone or in combination on the histology of liver and kidney of Labeo rohita. Pak. J. Zool., 45, 913-920 (2013).

Malik, A., J.D. Saroch, R. Srivastav, T.A. Qureshi and S. Manohar: Histological study of mercuric chloride effected Clarias gariepinus fed with spirulina. Int. J. Green Herbal Chem., 2, 139-148 (2013).

Mohamed, F.A.S.: Histopathological studies on Tilapia zilli and Solea vulgaris from lake Qarum, Egypt. World J. Fish Marine Sci., 1, 2939 (2009).

Obasohan, E.E., J.A.O. Oronsaye and O.I. Eguavoen: A comparative assessment of the heavy metal loads in the tissues of a common catfish, Clarias gariepinus from Ikpoba and Ogba rivers in Benin city. Nigeria. Afr. Sci., 9, 13-23 (2008).

Oliveira, Ribeiro, C.A., N.F. Filipack, M. Mela, P.H. Silva, M.A.F. Randi, J.R.A. Costa and E. Pelletier: Hematological findings in neotropical fish, Hoplias malabaricus exposed to sub chronic and dietary doses of methylmercury, inorganic lead and tributyltin chloride. Environ Resour., 101, 74-80 (2006).

Parvathi, K., P. Sivakumar and C. Sarasu: Effects of chromium on histopathological alterations on gill, liver and kidney of freshwater teleost, Cyprinus carpio (L). J. Fish. Inter., 6, 1-5 (2011).

Roy, S. and S. Bhattacharya: Arsenic induced histopathology and synthesis of stress proteins in liver and kidney of Channa punctatus. Eco. Environ. Saf., 65, 218-229 (2006).

Ruqaya, Y., S.H. Mir., M.M. Darzi and M.S. Mir: Metals and histopathological alterations in the kidneys of Schizothorax niger, Heckel from the Dal lake of Kashmir valley. J. Inter. Histopath., 1, 74-80 (2013).

Sirimongkolvorakul, S., T. Tansatit, N. Preyavichyapugdee, P. Kosai, K. Jiraungkoorskul and W. Jiraungkoorskul: Efficiency of Moringa oleifera dietary supplement reducing lead toxicity in Puntius altus. J. Med. Plant. Res., 6, 187-194 (2012).

Stouthart, A., F.A.T. Spanings, R.A.C. Lock and S.E.W. Bonga: Effects of low water $\mathrm{pH}$ on lead toxicity to early life stages of the common carp, Cyprinus carpio. Aqua. Toxicol., 30,137-151 (1994).

Thophon, S., M. Kruatrachue, E. Upatham, P. Pokethitiyook, S. Sahaphong and S. Jaritkhuan: Histopathological alterations of white sea bass, Lates calcarifer, in acute and subchronic cadmium exposure. Environ. Poll., 121, 307-320 (2003).

Wangsongsak, A., S. Utarnpongsa, M. Kruatrachue, M. Ponglikitmongkol, P. Pokethitiyook and T. Sumranwanich: Alterations of organ histopathology and metallolhionein mRNA expression in silver barb, Punctius gonionotus during subchronic cadmium exposure. J. Environ. Sci., 19, 1341-1348 (2007). 